\title{
No Evidence for Linkage Between HLA and Maturity Onset Type of Diabetes in Young People
}

\author{
P. Platz', B. K.Jakobsen', A.Svejgaard ${ }^{1}$, B.S. Thomsen ${ }^{2}$, K. B. Jensen ${ }^{2}$, K. Henningsen ${ }^{3}$ and L. U. Lamm ${ }^{4}$ \\ ${ }^{1}$ Tissue Typing Laboratory of the Blood Grouping Department, State University Hospital (Rigshospitalet), Copenhagen, \\ ${ }^{2}$ Medical Department, County Hospital, Ringkøbing, ${ }^{3}$ Institute of Forensic Medicine, University of Copenhagen, and \\ ${ }^{4}$ Tissue Typing Laboratory, University Hospital, Aarhus, Denmark
}

Summary. Studies with 20 different genetic marker systems were performed in a large kindred including 18 members affected with maturity onset type of diabetes of young people. Linkage closer than $0.1 \leqslant \theta$ could be excluded for $\mathrm{ABO}$ and
$\mathrm{Gm}$, and linkage closer than $0.05 \leqslant \theta$ for HLA, GLO, and haptoglobin. No significant positive lod scores were found.

Key words: Linkage, HLA, MODY, genetics of diabetes, heterogeneity.
Within the last decade it has been increasingly clear that diabetes mellitus is a heterogeneous group of diseases; in 1973-1975, the final proof was obtained that Type 1 (insulin-dependent) diabetes and Type 2 (non-insulin-dependent) diabetes are genetically different: only Type 1 is associated with certain HLA types [1,2,3]. At the same time, Tattersall and Fajans [4] described a third type of diabetes: maturity onset type of diabetes of young people (MODY), with onset in adolescence, autosomal dominant inheritance, no or very little insulin requirement, and very few microangiopathic complications. Barbosa et al. [5] have studied HLA types in one family with MODY and found evidence for linkage although this was not statistically significant. We present here a linkage study with 20 different genetic markers, including HLA, in one large kindred with MODY.

\section{Patients and Methods}

\section{Patients}

The kindred studied here consists of 53 members and was investigated and reported in detail by Johansen and Gregersen [6]. The individual numbers in the pedigree (Fig. 1) are the same as the individual numbers in Figure 1 in that report. All family members except a large branch without affected members (descendants of individual no. 7) were asked to participate in blood sampling. Blood samples were obtained from 18 affected and eight unaffected family members as well as eight spouses. Individual no. 1 was diagnosed as diabetic at the age of 40 years in 1929 ; all others affected were diagnosed before the age of 20 years. Only one of the unaffected individuals (no. 39) is less than 20 years old.

\section{Genetic markers}

The following genetic markers were determined: HLA (see below); twelve serum protein and red cell enzyme markers - haptoglobin $(\mathrm{Hp})$, group-specific component (Gc), immunoglobulin allotypes ( $\mathrm{Gm}$ and $\mathrm{Km})$, phosphoglucomutase, locus $1\left(\mathrm{PGM}_{1}\right)$, acid phosphatase $\left(\mathrm{AcP}_{1}\right)$, adenylate kinase $\left(\mathrm{AK}_{1}\right)$, 6-phosphogluconatedehydrogenase (PGD), glutamate pyruvate transaminase (GPT), carboxylesterase D (EsD), glutamate oxalate transaminase $\left(\mathrm{GOT}_{1}\right)$ and glyoxalase $\mathrm{I}(\mathrm{GLO})$; and seven blood group systems - ABO, Rhesus, Duffy, Kell, P, Lewis and Lutheran. The different genetic markers can be assigned to the following chromosomes according to the International System for Human Gene Nomenclature (1979) [7] (chromosome numbers in parentheses): HLA (6), Hp (16), Gc (4), GM (inconsistent 6 or 7), KM (7), $\mathrm{PGM}_{1}$ (1), $\mathrm{AcP}_{1}(2), \mathrm{AK}_{1}$ (9), PGD (1), GPT (unknown), EsD (13), GOT $(10)$, GLO (16), ABO (9), Rhesus (1), Duffy (1), Kell (unknown), P (6), Lewis (unknown), and Lutheran (unknown).

\section{HLA typing}

HLA typing for the HLA-A, B, and C antigens was performed as described previously [8]. We typed for the following specificities (splits are in parentheses): From the A series: A1, A2, A3, A9 (Aw23, Aw24), A10 (A25, A26), A11, A28, and Aw19 (A29, Aw30, Aw31, Aw32). From the B series: B5, B7, B8, B12 (Bw44, Bw45), B13, B14, B15, Bw16 (Bw38, Bw39), B17, B18, Bw21 (Bw49, Bw50), Bw22 (Bw55, Bw56), $\mathrm{B} 27, \mathrm{Bw} 35, \mathrm{~B} 37, \mathrm{~B} 40, \mathrm{Bw} 41, \mathrm{Bw} 47$, and Bw53. From the C series: Cw1, $\mathrm{Cw} 2, \mathrm{Cw} 3, \mathrm{Cw} 4$, and Cw6. In this paper B12 equals Bw44.

\section{Linkage analysis}

Lod scores $(z)$ were calculated with a slightly modified version of a previously described programme [9]. The main feature of this programme is the breaking down of each pedigree into a number of nuclear families consisting of a sibship with the parents and grandparents. These nuclear families are then analyzed separately, the lod scores being finally 


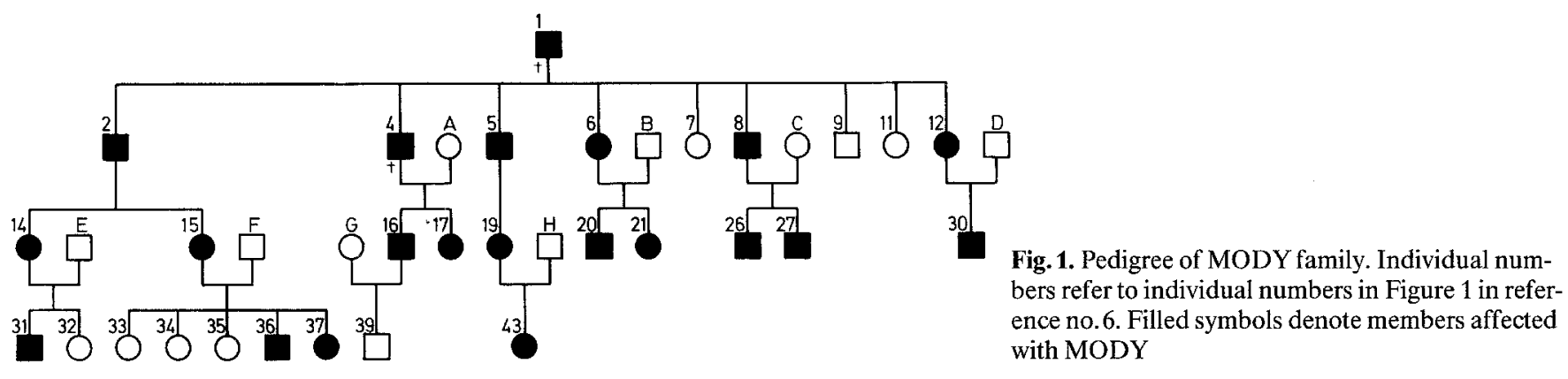

Table 1. HLA genotypes in MODY family

\begin{tabular}{|c|c|}
\hline $\begin{array}{l}\text { Individual number } \\
\text { (see Fig. 1) }\end{array}$ & $\begin{array}{l}\text { Paternal/maternal haplotype } \\
\text { HLA-A,C, B/ A, C, B }\end{array}$ \\
\hline 2 & $2, w 3,40 / 28, w 3,40$ \\
\hline 6 & 2, w3, 40/28, w3, 40 \\
\hline 7 & $2, w 3,40 / 1, w 4, w 35$ \\
\hline 8 & $2, w 3,40 / 28, w 3,40$ \\
\hline 9 & $2, w 3,40 / 28, w 3,40$ \\
\hline 11 & $2,-, w 38 / 8, w 3,40$ \\
\hline 12 & $2,-, w 38 / 28, w 3,40$ \\
\hline 14 & $2, w 3,40$ \\
\hline 15 & $2, w 3,40 / 1,-, 8$ \\
\hline 16 & $28, w 3,40 / 1,-, 12$ \\
\hline 17 & $28, w 3,40 / w 32, w 2,40$ \\
\hline 19 & $1, w 4, w 35 / 2,-7,7$ \\
\hline 20 & $1,-, 37 / 2, w 3,40$ \\
\hline 21 & $1,-, 37 / 28, w 3,40$ \\
\hline 26 & $2, w 3,40 / 28, w 4, w 35$ \\
\hline 27 & $2, w 3,40 / w 24, w 4, w 35$ \\
\hline 30 & $28,-, 14 / 28, w 3,40$ \\
\hline 31 & $w 19,-7 / 2, w 3,40$ \\
\hline 32 & w19, $-, 7 / 2, w 3,40$ \\
\hline 33 & $28, w 2,27 / 2, w 3,40$ \\
\hline 34 & $1,-, 8 / 2, w 3,40$ \\
\hline 35 & $1,-, 8 / 1,-, 8$ \\
\hline 36 & $1,-, 8 / 2, w 3,40$ \\
\hline 37 & $28, w 2,27 / 1,-, 8$ \\
\hline 39 & $28, w 3,40 / 24, w 3,15$ \\
\hline 43 & $1,-, 8 / 2,-, 7$ \\
\hline \multicolumn{2}{|l|}{ spouses } \\
\hline A & $1,-, 12 / \mathrm{w} 32, \mathrm{w} 2,40$ \\
\hline B & $1, \quad-37 / 3,-, 14$ \\
\hline C & w $24, w 4, w 35 / 28, w 4, w 35$ \\
\hline $\mathrm{D}$ & $28,-, 14 / 3, w 4, w 35$ \\
\hline $\mathrm{E}$ & $\mathrm{w} 19,-7 / 2,-$, w50 \\
\hline $\mathrm{F}$ & $28, w 2,27 / 1,-, 8$ \\
\hline $\mathrm{G}$ & $24, w 3,15 / 11, w 4,15$ \\
\hline $\mathrm{H}$ & $1, \quad-, 8 / 28, w 3,40$ \\
\hline
\end{tabular}

a Individual no.14 can on the maternal haplotype be either A2, Cw3, B40 or blank. - Denotes blank

summed over all nuclear families belonging to a pedigree. Lod scores were calculated for a standard set of recombination fractions $(\theta)$, i.e. $0.05,0.10,0.20,0.30$, and 0.40 . For each fraction, lod scores dependent on recombination in the fathers $(z \mathrm{~m})$ were kept separate from lod scores dependent on the mothers $(z \mathrm{f})$.

In contrast to previous versions, the programme now also analyses nuclear families in which neither of the parents (nor grandparents) were tested for the marker and where deduction of their genotypes was not possible. This is done by considering all possible genotypes, weighted with respect to their population frequencies as calculated from gene (or haplotype) frequencies available from population studies.
Due to limitations in the available computer storage capacity (CDC CYBER 173 system), the programme can maximally consider ten haplotypes in a given genetic system. This is sufficient for nearly all systems, even Rhesus, but not for HLA. In this case a simplified model with eight codominant haplotypes, $\mathrm{A}, \mathrm{B}, \mathrm{C}, \ldots \mathrm{H}$ of equal frequencies (i. e. 0.12375 ), and a rare null haplotype with a one percent frequency was adopted. The family members were then coded according to their deduced haplotypes which were labelled A, B, C ... H within each nuclear family. HLA haplotypes were deduced using all available typing data in the family, as apparent from Figure I and Table 1.

\section{Results}

Table 1 gives the HLA genotypes of all individuals in the pedigree (except for individuals nos.1, 4, and 5; Fig.1) and Table 2 gives the significant lod scores (by convention $<-2.0$ or $>3.0$ ) found in this family. No significant positive linkage to MODY was found for any of the 20 investigated genetic marker systems. HLA-haplotypes appear in Table 1. By simple inspection, tight linkage between HLA and the 'MODY' gene(s) is unlikely. For example, in the three-generation transmission (individuals nos. 2, 15, and 37) no haplotypes are transmitted from individual no. 2 to no.37. One pair of HLA-non-identical affected siblings is found and several HLA-identical individuals are discordant for the disease state.

Linkage analyses confirmed that close linkage between HLA and MODY can be excluded ( $z$ value of -2.7 for $\theta=0.05$ ). Linkage between MODY and ABO or Gm closer than between 10-20 centiMorgan, and for HLA, GLO, or Hp closer than between 5-10 centiMorgan, can be excluded.

Negative lod scores at $\theta=0.05$ of $-1.6,-1.4$, and -1.4 were obtained for Rhesus, GPT, and Gc, respectively. The remaining lod scores ranged between 0.002 and 0.255 at $\theta=0.05$.

\section{Discussion}

More than 30 distinct genetic disorders associated with carbohydrate intolerance have been described [for review 10]. Most of these syndromes are rare and collectively they comprise only a small fraction of all cases of diabetes. However, their existence illustrates the point that diabetes is just a syndrome which may cover several different aetiologies. 
Table 2. Lod scores for genetic markers showing significant negative linkage with MODY

\begin{tabular}{|c|c|c|c|c|c|c|c|c|c|c|c|c|c|c|c|}
\hline \multirow{2}{*}{$\begin{array}{l}\text { Recom- } \\
\text { bination } \\
\text { frequency } \\
\theta\end{array}$} & \multicolumn{3}{|l|}{ HLA } & \multicolumn{3}{|c|}{ Glyoxalase 1} & \multicolumn{3}{|c|}{$\mathrm{ABO}$ blood group } & \multicolumn{3}{|c|}{$\begin{array}{l}\text { Immunoglobulin allotype } \\
(\mathrm{Gm})\end{array}$} & \multicolumn{3}{|c|}{ Haptoglobin (Hp) } \\
\hline & $\begin{array}{l}\text { Pater- } \\
\text { nal }\end{array}$ & $\begin{array}{l}\text { Mater- } \\
\text { nal }\end{array}$ & $\begin{array}{l}\text { Com- } \\
\text { bined }\end{array}$ & $\begin{array}{l}\text { Pater- } \\
\text { nal }\end{array}$ & $\begin{array}{l}\text { Mater- } \\
\text { nal }\end{array}$ & $\begin{array}{l}\text { Com- } \\
\text { bined }\end{array}$ & $\begin{array}{l}\text { Pater- } \\
\text { nal }\end{array}$ & $\begin{array}{l}\text { Mater- } \\
\text { nal }\end{array}$ & $\begin{array}{l}\text { Com- } \\
\text { bined }\end{array}$ & $\begin{array}{l}\text { Pater- } \\
\text { nal }\end{array}$ & $\begin{array}{l}\text { Mater- } \\
\text { nal }\end{array}$ & $\begin{array}{l}\text { Com- } \\
\text { bined }\end{array}$ & $\begin{array}{l}\text { Pater- } \\
\text { nal }\end{array}$ & $\begin{array}{l}\text { Mater- } \\
\text { nal }\end{array}$ & $\begin{array}{l}\text { Com- } \\
\text { bined }\end{array}$ \\
\hline 05 & -0.21 & -2.443 & -2.647 & 0.0 & -2.442 & -2.442 & 045 & -3.794 & -3.749 & \multicolumn{2}{|c|}{$-0.295-3.442$} & -3.837 & 0.079 & -2.721 & -2.642 \\
\hline 0.10 & -0.01 & $2-1.587$ & -1.599 & 0.0 & -1.586 & -1.586 & 0.036 & -2.597 & -2.561 & \multicolumn{2}{|c|}{$-0.174-2.285$} & -2.459 & 0.064 & -1.842 & -1.776 \\
\hline 0.20 & 0.07 & -0.786 & -0.713 & 0.0 & -0.786 & -0.786 & 0.020 & -1.419 & -1.399 & \multicolumn{2}{|c|}{$-0.029-1.184$} & -1.213 & 0.037 & -0.990 & -0.953 \\
\hline
\end{tabular}

Lod scores are calculated for paternal and maternal as well as combined segregation at different recombination frequencies $(\theta)$.

Type 1 diabetes has now been clearly separated from Type 2 diabetes not only on the basis of the HLA association, but also on the basis of concordance rate in monozygotic twins in that less than $50 \%$ of Type 1 monozygotic twins are concordant for diabetes, while nearly all Type 2 monozygotic twins become concordant [11]. Furthermore, heterogeneity within Type 1 diabetes is suspected but has not yet been proven [12].

MODY is clinically separated from Type 2 diabetes by age-at-onset criteria and from Type 1 diabetes by its clear, dominant mode of inheritance. Whether MODY like Type 1 diabetes is linked to HLA has previously been unclear. Barbosa et al. [5] have claimed evidence for linkage between MODY and HLA $(5,13)$, although the lod scores were not significant $(z=1.976$ for $\theta=0.05$ ), whereas Nelson and Pyke [14] and Faber et al. [15] found no evidence for linkage, although no formal linkage analysis was performed in the two latter studies.

The clinical picture investigated in our study is very similar to those described by others. The lod scores found here excluded close linkage between MODY and HLA in this family. Whether this means that MODY is heterogeneous and consists of an HLA-linked and a non-HLA-linked form, or whether the positive lod scores found by Barbosa et al. [5] were a chance deviation, remains to be clarified.

Acknowledgements. This work was supported by grants from the Danish Medical Research Council, the Dagmar Marshall Foundation and Ringkøbing County Council. Drs. K. Johansen and G. Gregersen are thanked for helpful discussions and Mrs. C. Dam-Sørensen typed the manuscript.

\section{References}

1. Singal DP, Blajchman MA (1973) Histocompatibility (HL-A) antigens, lymphocytotoxic antibodies and tissue antibodies in patients with diabetes mellitus. Diabetes 22: 429-432

2. Nerup J, Platz P, Andersen OO, Christy M, Lyngsøe J, Poulsen JE,
Ryder LP, Nielsen LS, Thomsen M, Svejgaard A (1974) HL-A antigens and diabetes mellitus. Lancet 2:864-866

3. Cudworth AG, Woodrow JC (1975) Evidence for HL-A linked genes in 'juvenile' diabetes mellitus. Br Med J 3: 133-135

4. Tattersall RB, Fajans SS (1975) A difference between the inheritance of classical juvenile-onset and maturity-onset type diabetes of young people. Diabetes 24:44-53

5. Barbosa J, King R, Goetz FC, Noreen H, Yunis EJ (1978) HLA in maturity-onset type of hyperglycemia in the young. Arch Intern Med 138:90-93

6. Johansen K, Gregersen G (1977) A family with dominantly inherited mild juvenile diabetes. Acta Med Scand 201 : 567-570

7. Shows TB, McAlpine PJ (1979) The 1979 catalog of human genes and chromosome assignments. Cytogenet Cell Genet 25: 117-127

8. Kissmeyer-Nielsen F, Kjerbye KE (1967) Lymphocytotoxic microtechnique purification of lymphocytes by flotation. In: Curtoni ES, Mattiuz PL, Tosi RM (eds) Histocompatibility testing 1967. Munksgaard, Copenhagen, pp 381-383

9. Lamm LU, Thorsen I, Petersen GB, Jørgensen J, Henningsen K, Bech B, Kissmeyer-Nielsen F (1975) HL-A linkage group. Ann Hum Genet 38: 383-390

10. Rimoin DL (1976) Genetic syndromes associated with glucose intolerance. In: Creutzfeldt W, Köbberling J, Neel JV (eds) The genetics of diabetes mellitus. Springer, Berlin, pp 43-63

11. Barnett AH, Eff C, Leslie RDG, Pyke DA (1981) Diabetes in identical twins. Diabetologia 20:87-93

12. Svejgaard A, Platz P, Ryder LP (1980) Insulin-dependent diabetes mellitus. In: Terasaki PI (ed) Histocompatibility testing 1980. University of California, Los Angeles, pp 638-656

13. Barbosa J, Noreen H, Doe RP, Yunis EJ (1976) The genetic heterogeneity of diabetes: Histocompatibility antigens (HLA) in families with maturity-onset type diabetes of the young (MODY), and juvenile, insulin dependent diabetes (JID). Diabetes 25:336 (Abstract)

14. Nelson IG, Pyke RA (1976) Genetic diabetes not linked to the HLA locus. Br Med J 1: 196-197

15. Faber OK, Thomsen M, Binder C, Platz P, Svejgaard A (1978) HLA antigens in a family with maturity-onset type diabetes mellitus. Acta Endocrin 88: 329-338

Received: 3 December 1981

and in revised form: 21 January 1982

Per Platz

Tissue Typing Laboratory

State University Hospital (Rigshospitalet)

Blegdamsvej 9

DK-2100 Copenhagen $\varnothing$, Denmark 